\title{
ANALISIS PERFORMANCE LEVEL SENDI PLASTIS LOKAL PADA FONDASI TIANG TUNGGAL DAN TIANG KELOMPOK
}

\author{
Willy Ericson $^{1}$, Hendy Wijaya ${ }^{2}$, dan Amelia Yuwono ${ }^{3}$ \\ ${ }^{1}$ Program Studi Sarjana Teknik Sipil, Universitas Tarumanagara, Jl. Letjen S. Parman No.1 Jakarta \\ Willy.325130096@stu.untar.ac.id \\ ${ }^{2}$ Program Studi Sarjana Teknik Sipil, Universitas Tarumanagara, Jl. Letjen S. Parman No.1 Jakarta \\ rm.hendy@yahoo.com \\ ${ }^{3}$ Program Studi Sarjana Teknik Sipil, Universitas Tarumanagara, Jl. Letjen S. Parman No.1 Jakarta \\ yuwonoamelia@gmail.com
}

\begin{abstract}
Foundation is part of the structure that was build first and the most important part to guarantee the establishment of a building. The foundation function in general are to carry and distribute building loads into the ground. The loads channeled into the ground in the form of axial loads and lateral loads. Generally for high buildings used in the form of foundation piles or bored piles. To find out the design capabilities of a building in maintaining its robustness, naturally some analysis of the lower and upper structures needed. Especially in the lower structure, which is the foundation of a single pile or a group of piles, one of which can be done is a pushover analysis of the pile. By conducting pushover analysis on a pile foundation, the level of performance of the single pile foundation and group pile can be determined. From the results of pole pushover analysis will be obtain including the maximum deflection value and the melting value of pole. From the two data, it can be seen the value of the ductility of various types of pile foundation materials used. In this case, this journal will calculate the ductility and overstrength of a single pile foundation and group pile with variation dimensions.
\end{abstract}

Keywords: single pile foundation; pile group foundation; ductility of pile; overstrength

\begin{abstract}
ABSTRAK
Fondasi merupakan bagian struktur yang dikerjakan paling awal dan bagian yang terpenting untuk menjamin berdirinya suatu bangunan. Fungsi fondasi pada umumnya adalah memikul dan menyalurkan beban bangunan ke dalam tanah. Beban yang disalurkan ke dalam tanah berupa beban aksial dan beban lateral. Umumnya untuk bangunan tinggi digunakan fondasi dalam berupa tiang pancang atau tiang Bor. Untuk mengetahui kemampuan desain suatu bangunan dalam mempertahankan kekokohannya, tentu diperlukan beberapa analisis terhadap struktur bawah dan struktur atas. Terutama pada bagian stuktur bawah, yaitu fondasi tiang tunggal atau tiang kelompok salah satunya dapat dilakukan analisis pushover tiang. Dengan melakukan analisis pushover pada suatu fondasi tiang, tingkat kinerja fondasi tiang tunggal maupun tiang kelompok dapat diketahui. Dari hasil analisis pushover tiang akan didapatkan diantaranya nilai defleksi maksimum dan nilai leleh dari suatu tiang. Dari kedua data tersebut, dapat diketahui nilai daktilitas berbagai jenis material fondasi tiang yang digunakan. Pada halnya, jurnal ini akan menghitung nilai daktilitas dan kekuatan berlebih (overstrength) dari suatu fondasi tiang tunggal dan tiang kelompok dengan variasi dimensi.
\end{abstract}

Kata kunci: fondasi tiang tunggal; fondasi tiang kelompok; daktilitas tiang; overstrength

\section{PENDAHULUAN}

Dari berbagai jenis-jenis fondasi, salah satu jenis fondasi yang sering digunakan untuk bangunan tinggi adalah fondasi tiang pancang dan fondasi tiang bor. Pemakaian tiang pancang dan tiang bor sendiri diperuntukkan saat kondisi tanah dasar di bawah bangunan tersebut tidak mempunyai daya dukung (Bearing Capacity) yang cukup untuk memikul berat bangunan. Beban yang dipikul sebuah tiang tidak hanya berasal dari beban aksial saja, tetapi tedapat pula beban lateral. Beban lateral dapat terjadi karena adanya gempa, angin, dan gelombang air laut, oleh karena itu perlu dilakukanan analisis dan desain terhadap beban lateral harus diperhitungkan agar tiang pancang berfungsi dengan baik. Salah satu program yang dapat digunakan sebagai analisis beban lateral adalah program 
Lpile untuk tiang tunggal atau Group untuk tiang kelompok dari ensoft inc. Analisis lateral fondasi tiang tunggal atau tiang kelompok dilakukan untuk menghasilkan kurva beban lateral versus displacement.

\section{Tiang pancang}

Fondasi tiang pancang adalah konstruksi yang umumnya terbuat dari kayu, beton, dan/atau baja yang digunakan untuk meneruskan (mentransmisikan) beban-beban permukaan ke tingkat-tingkat permukaan yang lebih rendah di dalam massa tanah (Bowles 1991). Tanah di sekitar fondasi tiang pancang dapat berpindah yang disebabkan oleh fondasi tersebut. Pondasi tiang pancang dapat diklasifikasikan berdasarkan cara pemindahan beban, berdasaikan bahan yang digunakan, fungsi serta bentuk tiang.

\section{Tiang kelompok}

Kemungkinan konstruksi terdiri dari sebuah tiang-pancang tunggal pondasi sangat jarang. Umumnya, paling sedikit dua atau tiga tiang-pancang di bawah elemen fondasi atau kaki fondasi dikarenakan masalah penjajaran dan eksentrisitas yang kurang baik. Peraturan Bangunan Chicago (Pasal 70.4) mengatakan: "Sebuah kolom atau pir yang ditopang oleh tiang pancang harus tinggal diam di atas tidak kurang dari tiga tiang-pancang". Berikut gambar dibawah ini merupakan pola-pola kelompok tiang pancang khusus.

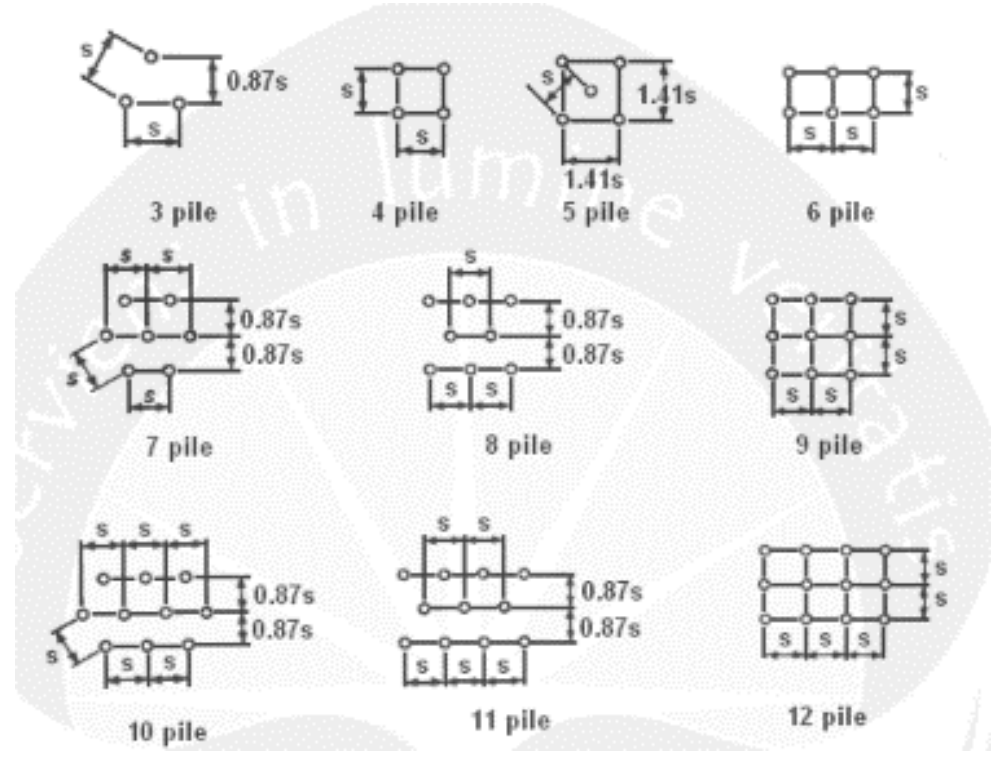

Gambar 1. Pola susunan tiang pancang; ( $s=$ minimum pile spacing)

(Sumber: Wayne C. T., 1962)

\section{Daktilitas}

Daktilitas adalah kemampuan suatu struktur untuk mengalami simpangan pasca elastis yang besar secara berulang kali dan bolak-balik akibat beban gempa diatas beban gempa yang menyebabkan terjadinya pelelehan pertama, sambil mempertahankan kekuatan dan kekakuan yang cukup, sehingga struktur tersebut tetap berdiri, meski sudah berada dalam kondisi diambang keruntuhan (SNI 03-1726-2002). Faktor daktilitas dinyatakan dalam term displacement, rotation maupun curvature:

$$
\begin{aligned}
\mu \Delta & =\frac{\Delta u}{\Delta y} \\
\mu \Phi & =\frac{\Phi \mu}{\Phi y} \\
\mu \theta & =\frac{\boldsymbol{\theta} \boldsymbol{\mu}}{\boldsymbol{\theta y}}
\end{aligned}
$$

dengan $\mu \Delta=$ daktilitas defleksi/lendutan, $\Delta \mathrm{u}$ adalah displacement pada keadaan batas post-elastis dan $\Delta \mathrm{y}=$ displacement pada keadaan leleh yang pertama.

Berdasarkan SNI 2847-03-2002 dan the seismic loading in the new zeland loading code for ductility frame, suatu struktur diisyaratkan paling sedikit mempunyai factor displacement ductility $=4$, sedangkan the tentative provisions of the ACT for ductility frames mensyaratkan minimal 7. Besarnya lateral displacement dihitung dengan teori momen area, dimana pada saat leleh pertama: 


$$
\Delta y=\frac{\emptyset y \cdot L}{2}+\frac{\emptyset 2 L}{3}=\frac{\emptyset y \cdot L^{2}}{3}
$$

Lateral displacement pada saat ultimate:

$$
\begin{aligned}
& \Delta \mu=\Delta y+\emptyset p \cdot\left(1-\frac{l p}{2}\right) \\
& \Delta \mu=\frac{\phi y \cdot L^{2}}{3}+(\varnothing \mu-\emptyset y) \cdot l p \cdot\left(1-\frac{l p}{2}\right) \\
& \left.\mu=\frac{\Delta \mu}{\Delta y}=1+\left(\frac{\phi \mu-\emptyset y}{y}\right) \cdot \frac{l p \cdot(1-0.5 \cdot l p)}{L^{2} / 3}\right) \\
& \frac{\mu}{y}=1+\frac{L^{2}(\mu-1)}{3 l p(L-0.5 l p)}
\end{aligned}
$$

dengan $\mathrm{L}=$ Tinggi tiang pancang, $\mu=$ displacement ductility, $l p=$ panjang sendi plastis.

\section{Overstrength}

Berdasarkan buku peraturan kode gempa, bangunan diperbolehkan untuk diberikan kuat-lebih (overstrength) structural untuk melawan gempa. Kuat-lebih adalah kekuatan yang terjadi ketika sendi plastis terbentuk pada struktur. Kuat-lebih membantu struktur untuk bertahan melawan gaya gempa sekaligus mengurangi ketahanan elastic pada bangunan. Hasil studi telah menunjukkan secara luas bahwa overstrength bergantung pada beberapa faktor dan yang paling utama adalah daktilitas rangka. Dalam (Propika, Jaka dan Jenny Caroline, 2017) didapatkan bahwa bentuk dan daktilitas dari struktur sangat mempengaruhi overstrength factor.

\section{Hubungan antara overstrength dan kekuatan desain}

Kuat-lebih (overstrength) ditetapkan sebagai kapasitas dari sebuah struktur yang dapat didefinisikan sebagai perbandingan geser dasar maksimum dalam perilaku aktuel terhadap kekuatan leleh signifikan dalam struktur. Dapat dilihat hubungan nilai displacement diletakkan searah pada sumbu $\mathrm{x}$ dan nilai shear diletakkan searah sumbu y pada gambar 2. di bawah ini.

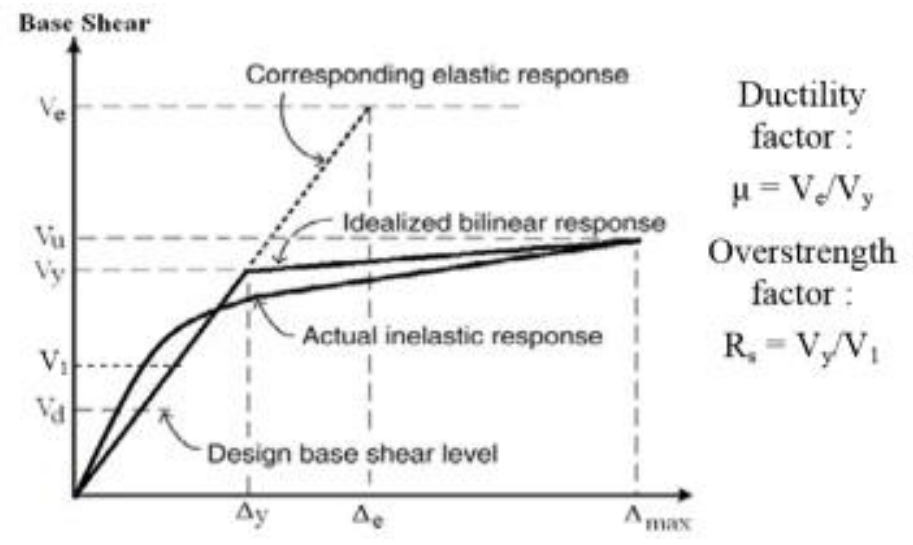

Gambar 2. Hubungan antara base shear dengan roof displacement

\section{Software Lpile}

LPILE adalah program komputer dengan tujuan khusus dan diakui secara internasional berdasarkan prosedur rasional untuk menganalisis tumpukan di bawah beban lateral menggunakan metode p-y. LPILE memecahkan persamaan diferensial untuk balok-kolom menggunakan pendekatan beda hingga. Program menghitung defleksi, momen lentur, gaya geser, dan respons tanah terhadap panjang tiang. Pemindahan beban lateral nonlinier dari fondasi ke tanah dimodelkan menggunakan kurva p-y yang dihasilkan secara internal untuk berbagai jenis tanah, atau kurva $p-y$ yang diinput oleh pengguna. Prosedur khusus juga tersedia untuk menghitung kurva $p-y$ untuk tanah dan batuan berlapis. Dengan rilis rilis komersial pertama sejak tahun 1986, LPILE terus dikembangkan dan ditingkatkan untuk memenuhi kebutuhan pengguna dan menggabungkan literatur dan prosedur canggih. Berdasarkan contoh hasil output running program untuk melihat nilai minimum dan minimum dari shear force dapat di lihat pada gambar 3. di bawah ini. 


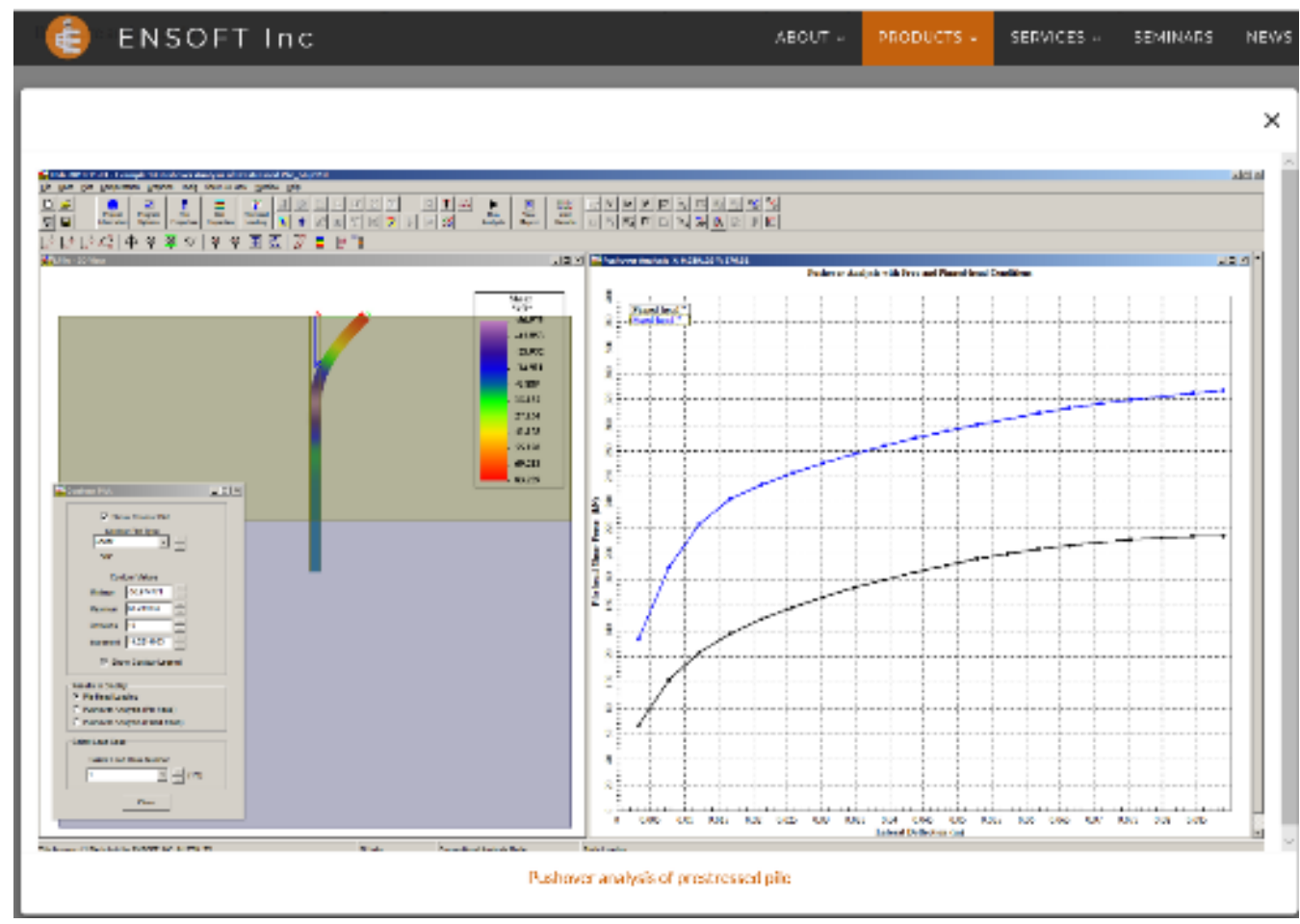

Gambar 3. Hasil running pada program Lpile

\section{Software Group}

Group Pile adalah software yang diterima dengan baik untuk menganalisis perilaku kelompok tiang yang mengalami pemuatan aksial dan lateral. Program ini dikembangkan untuk menghitung distribusi beban (vertikal, lateral, dan menjungkirbalikkan momen hingga tiga sumbu ortogonal) yang diterapkan dari berbagai lokasi di pile cap hingga pile yang disusun dalam kelompok.

Program ini menghasilkan secara internal respon nonlinier tanah, dalam bentuk kurva t-z dan Q-w untuk pembebanan aksial, dalam bentuk kurva p-y untuk pembebanan lateral dan dalam bentuk kurva T-q untuk pembebanan torsional. Solusi memerlukan iterasi untuk mengakomodasi respons nonlinier dari setiap tiang dalam model kelompok. Program GROUP memecahkan respons nonlinier dari masing-masing tiang di bawah pemuatan gabungan dan memastikan kompatibilitas deformasi dan keseimbangan gaya antara beban eksternal yang diterapkan dan reaksi dari masing-masing kepala tiang. Berdasarkan contoh hasil output running program untuk melihat nilai defleksi, lateral, momen dan reaksi tanah dapat dilihat pada gambar 4. di bawah ini.

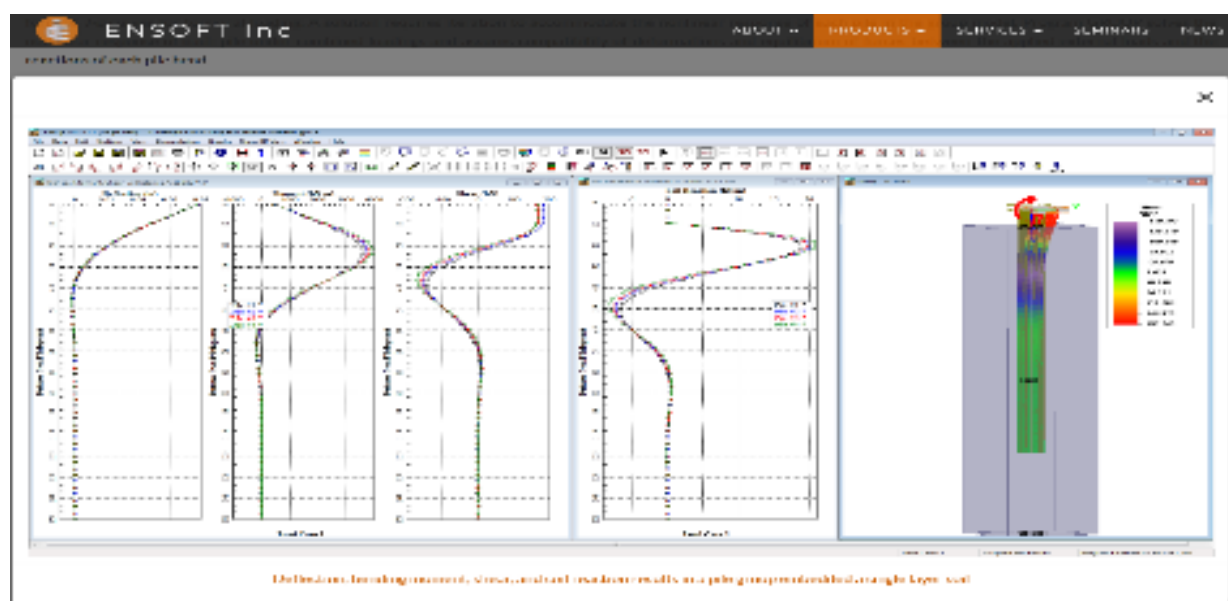

Gambar 4. Hasil running pada program Group 


\section{METODE PENELITIAN}

\section{Tahapan penelitian}

Berikut adalah diagram alir metodologi penelitian:

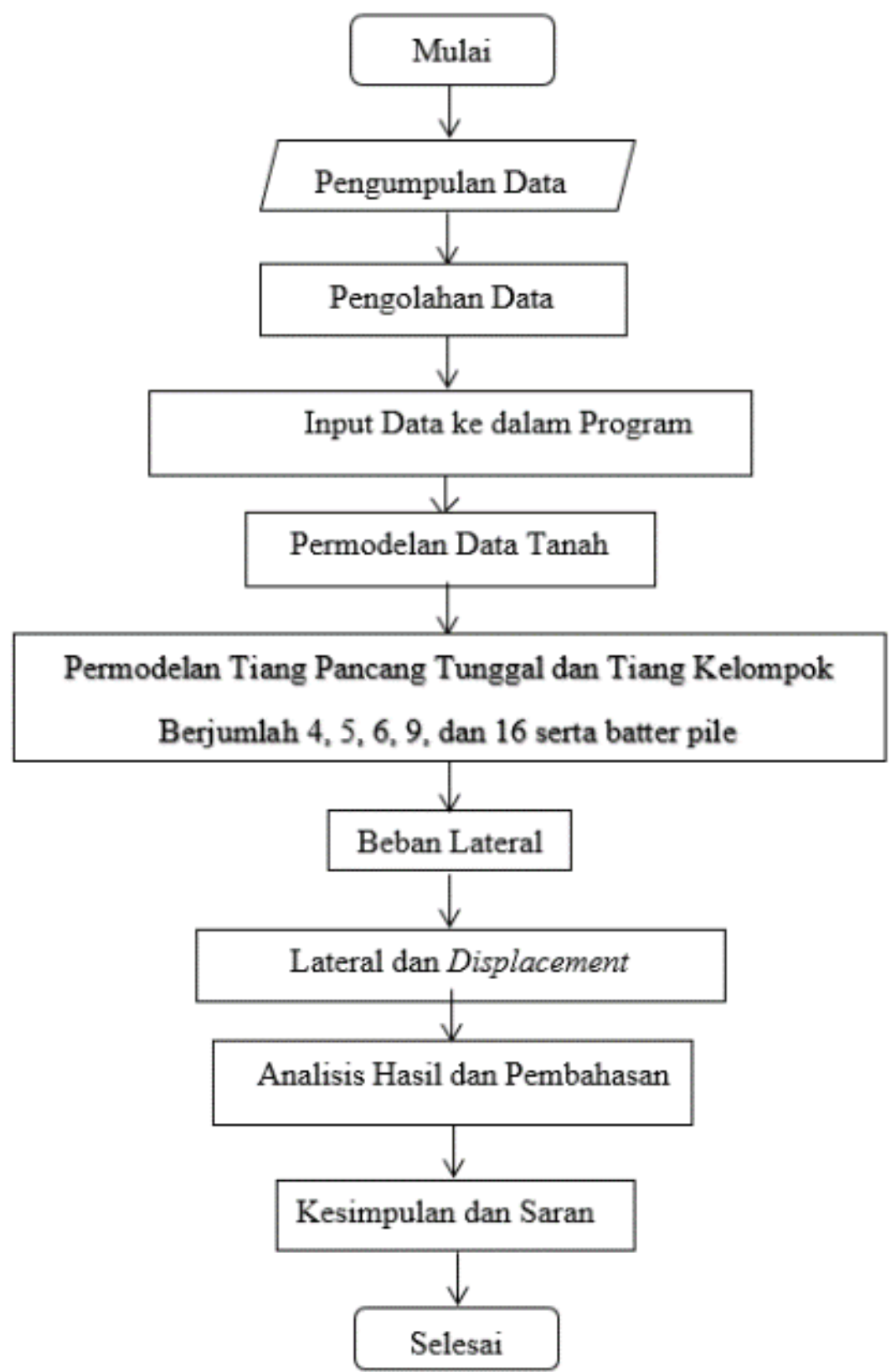

Gambar 5. Diagram alir penelitian

\section{Pengumpulan data}

Data tanah yang dikumpulkan berupa boring $\log$ dan hasil tes laboratorium. Data tanah tersebut merupakan laporan penyelidikan tanah pada daerah tersebut.

\section{Pengolahan data}

Sebelum dilakukan pengolahan data, dilakukan studi literatur untuk memahami dasar-dasar teori yang perlu diperhatikan dan rumus-rumus yang digunakan untuk analisis. Setelah dilakukan studi literatur, data-data yang telah dikumpulkan dimasukan ke dalam program dengan memasukkan parameter-parameter yang telah ditentukan seperti beban lateral, jenis tanah, dan dimensi tiang. 


\section{Metode analisis data}

Metode analisis yang digunakan adalah Pushover Analysis yang terdapat pada program Lpile dan Group. Program berbasis geoteknik ini mampu menganalisis kekuat tiang terhadap beban yang diberikan. Nilai yang paling umum dapat diketahui dengan program ini diantaranya, nilai aksial, lateral, dan momen yang mampu diterima oleh tiang. Dalam kasus ini, nilai lateral dan displacement yang diketahui kemudian diplot menjadi grafik beban lateral versus displacement. Hasil plotan grafik diharapkan dapat merepresentasikan nilai leleh awal dan ultimate dari sebuah tiang pancang tunggal dan tiang kelompok untuk melakukan perhitungan nilai overstrength dan daktilitas dengan manarik garis area keseimbangan atas dan bawah (approximately balance areas above and below) pada grafik.

\section{HASIL DAN PEMBAHASAN}

\section{Data beban lateral dan displacement}

Data beban lateral dan displacement didapatkan melalui hasil output running program Lpile dan Group dan diolah dalam bentuk grafik beban lateral versus displacement. Sebanyak 440 grafik didapatkan dari hasil running program dengan berbagai ketentuan seperti jenis tiang, jarak antar tiang, kondisi tiang dan variasi dimensi tiang. Dari setiap grafik dilakukan penarikan garik lurus sebagai area batas atas dan bawah (approximately balance areas above and below) untuk menentukan nilai overstrength dan daktilitas tiang pancang. Proses penginputan data koefisien lateral, displacement, spesifikasi tiang, ketebalan tanah dan koordinat tiang pada tiang tunggal dan tiang kelompok dapat dilihat pada gambar 6. s/d gambar 14 . di bawah ini.

\section{Proses penginputan data}

1. Pemberian Beban

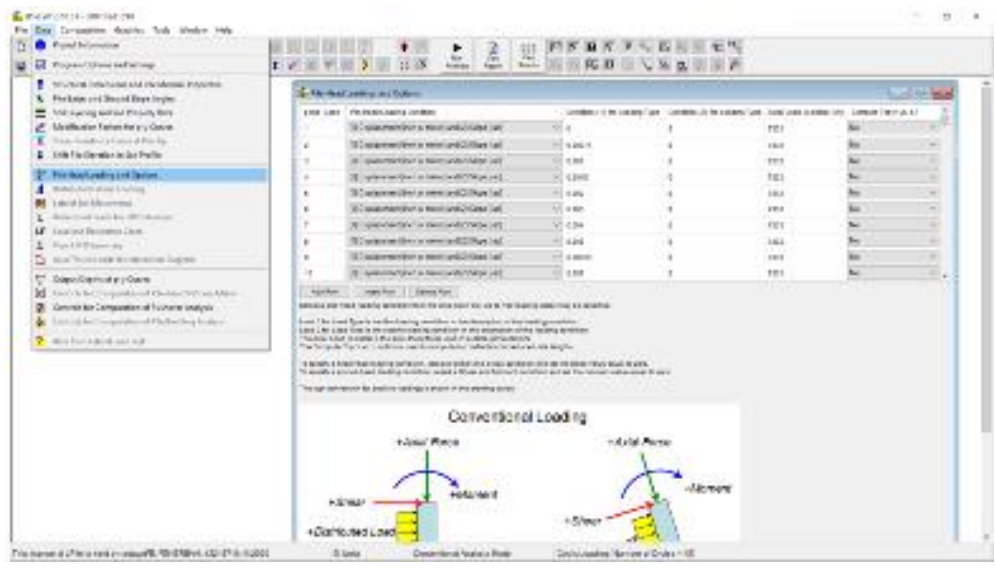

Gambar 6. Tampilan proses input beban pada tiang tunggal

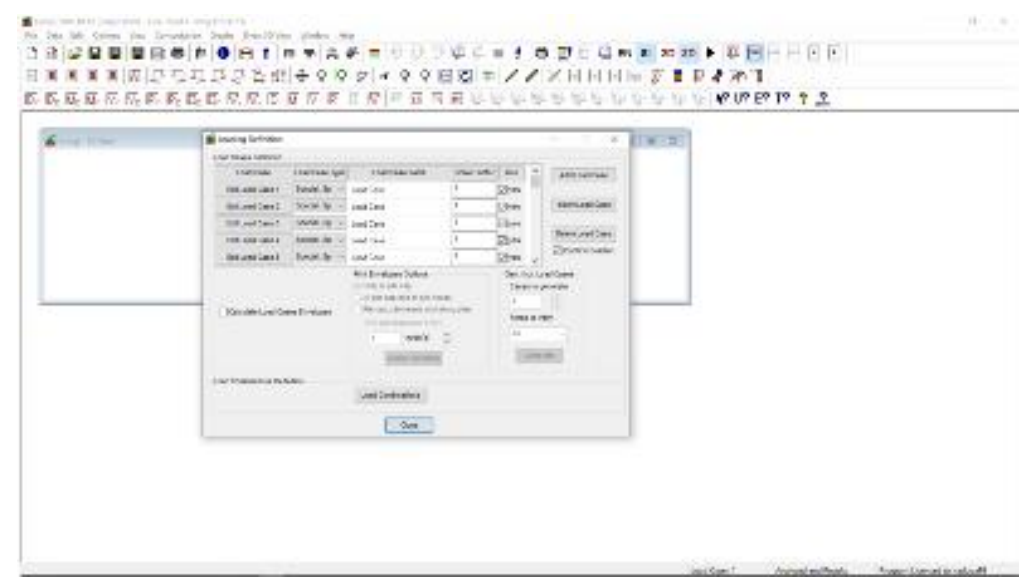

Gambar 7. Tampilan proses input pembebanan pada kepala tiang kelompok 
2. Spesifikasi Tiang

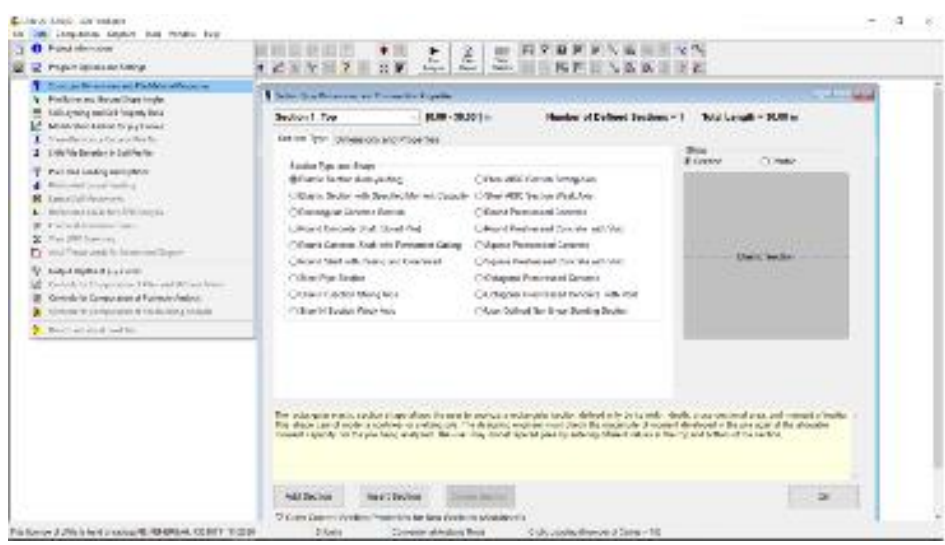

Gambar 8. Tampilan proses input spesifikasi tiang tunggal

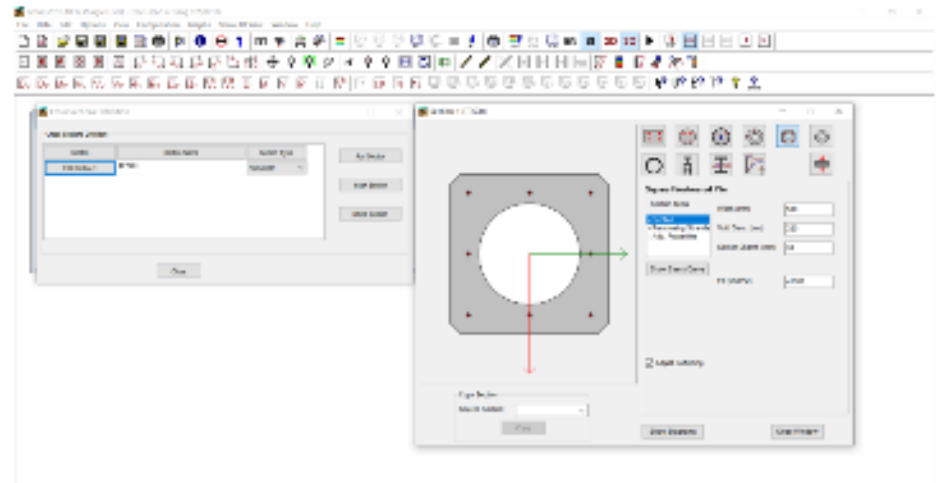

Gambar 9. Tampilan proses input spesifikasi tiang kelompok

3. Kedalaman Tanah

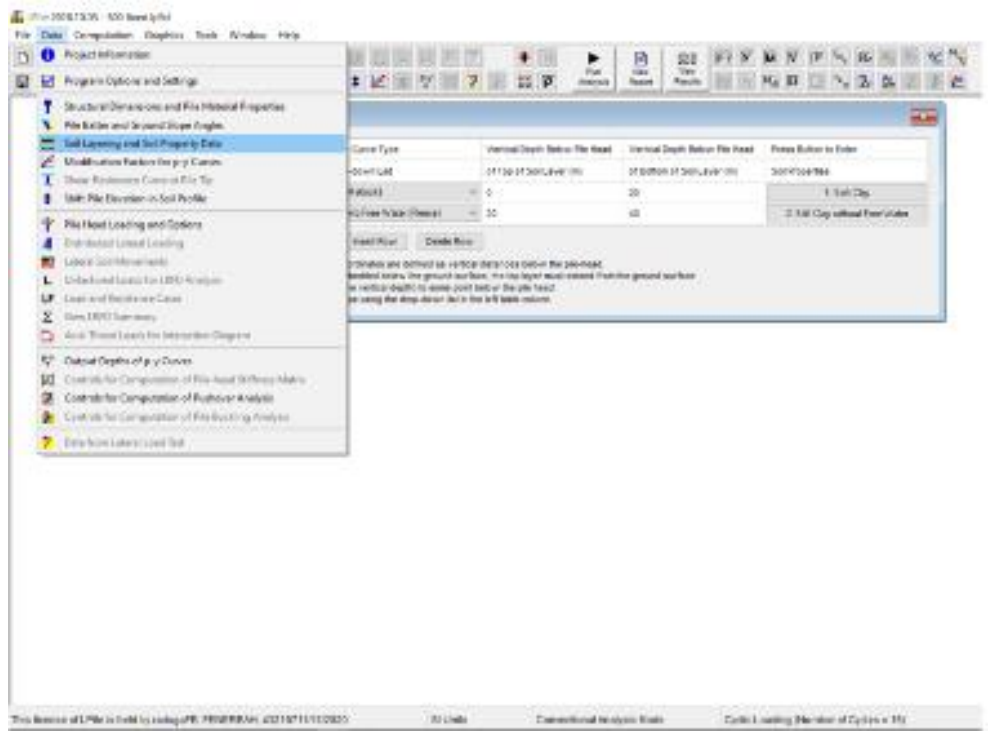

Gambar 10. Tampilan proses input jenis dan kedalaman tanah tiang tunggal 
Analisis Performance Level Sendi Plastis Lokal pada Fondasi

Willy Ericson, et al. Tiang Tunggal dan Tiang Kelompok

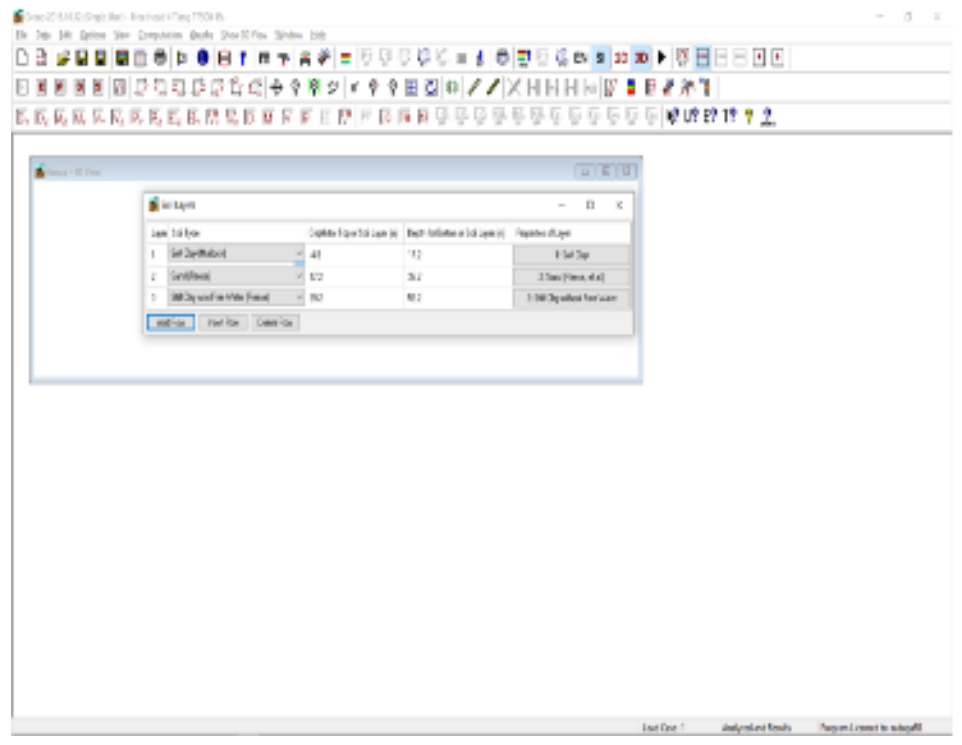

Gambar 11. Tampilan proses input jenis dan kedalaman tanah tiang kelompok

4. Koordinat Tiang Kelompok

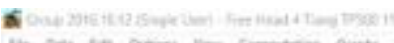

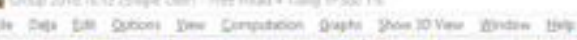

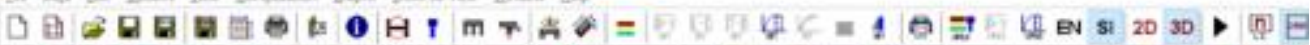

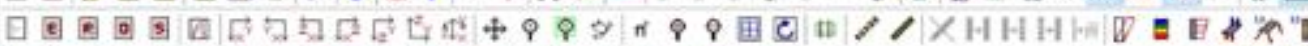

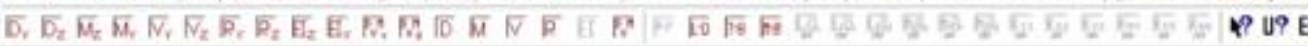

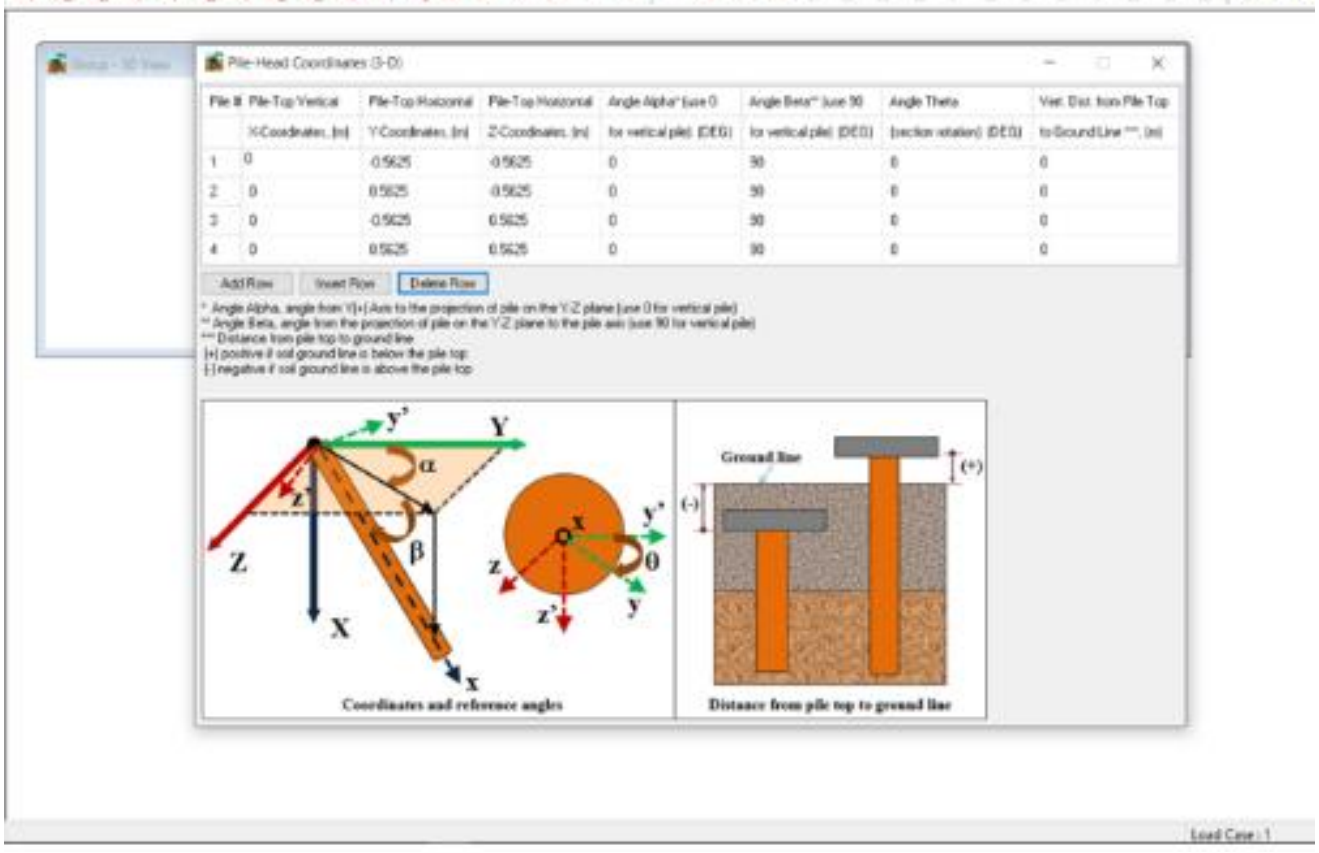

Gambar 12. Tampilan proses input titik koordinat tiang pada pile cap 


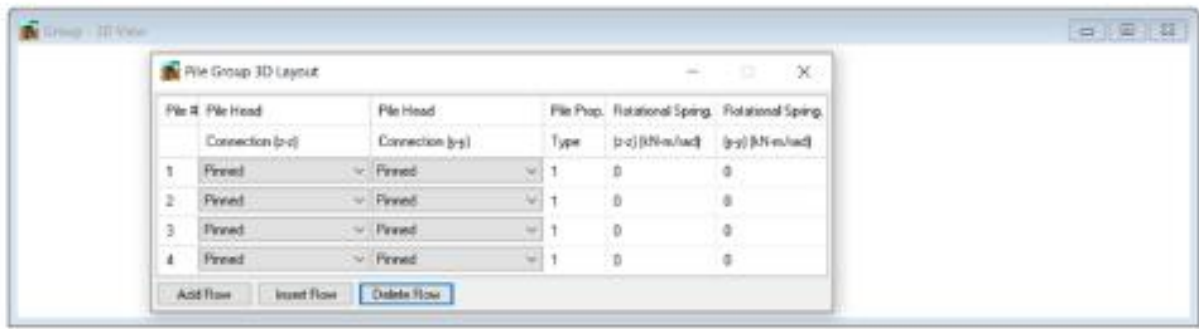

Gambar 13. Tampilan proses pemilihan fungsi kepala tiang kelompok

6. Dimensi Pile Cap

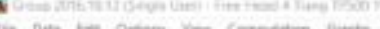

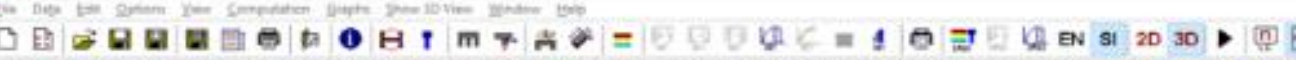

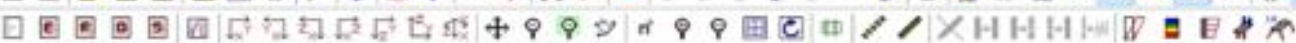

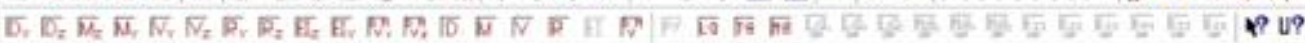

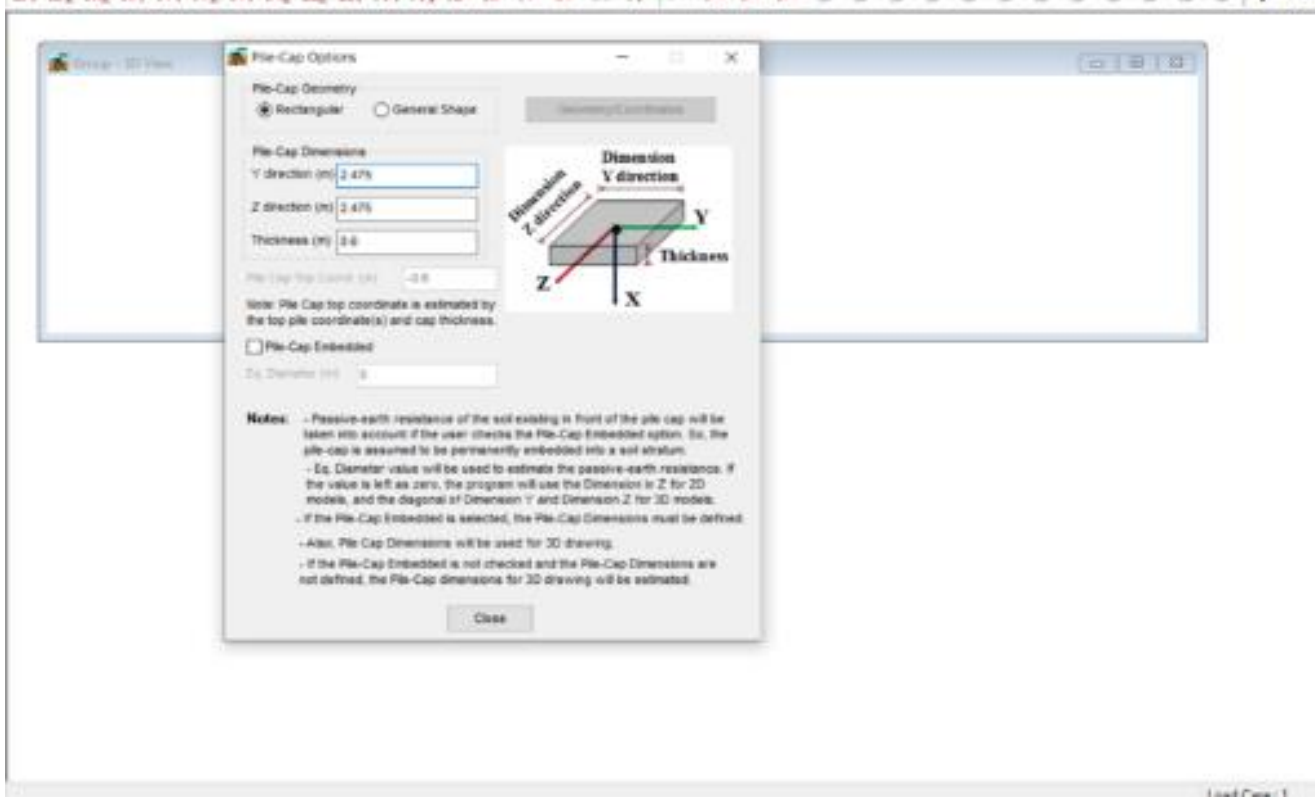

Gambar 14. Tampilan proses input dimensi pile cap 


\section{Hasil analisa grafik daktilitas dan overstrength}

Nilai hasil output berdasarkan running program Lpile dengan ketentuan kepala tiang, jenis tiang dan dimensi berbeda-beda untuk tiang tunggal dapat dilihat pada tabel 1. dan tabel 2., sedangkan nilai hasil output berdasarkan running program Group untuk tiang kelompok dapat dilihat pada tabel 3. s/d tabel 10. di bawah ini.

Tabel 1. Hasil perhitungan nilai overstrength dan ductility pada tiang tunggal non-elastik saat kondisi fix head dan free head

\begin{tabular}{|c|c|c|c|c|c|c|c|c|}
\hline \multicolumn{9}{|c|}{ Tiang Tunggal Non-Elastik } \\
\hline \multirow{3}{*}{$\begin{array}{l}\text { Dimensi } \\
(\mathrm{mm})\end{array}$} & \multicolumn{4}{|c|}{ Persegi Beton } & \multicolumn{4}{|c|}{ Spun Pile } \\
\hline & \multicolumn{2}{|c|}{ Fix Head } & \multicolumn{2}{|c|}{ Free Head } & \multicolumn{2}{|c|}{ Fix Head } & \multicolumn{2}{|c|}{ Free Head } \\
\hline & OS & DUC & OS & DUC & OS & DUC & OS & DUC \\
\hline 300 & 1,27 & 3,00 & 1,18 & 3,33 & 1,30 & 3,00 & 1,25 & 3,33 \\
\hline 350 & 1,21 & 4,00 & 1,14 & 3,50 & 1,25 & 4,00 & 1,10 & 3,50 \\
\hline 400 & 1,27 & 4,00 & 1,19 & 3,75 & 1,23 & 4,00 & 1,11 & 3,75 \\
\hline 450 & 1,30 & 4,00 & 1,15 & 3,80 & 1,29 & 4,00 & 1,11 & 3,80 \\
\hline 500 & 1,30 & 4,00 & 1,18 & 4,00 & 1,33 & 4,00 & 1,26 & 4,00 \\
\hline
\end{tabular}

Tabel 2. Hasil perhitungan nilai overstrength dan ductility pada tiang tunggal elastik saat kondisi fix head dan free head

\begin{tabular}{ccccccccc}
\hline & \multicolumn{9}{c}{ Tiang Tunggal Non-Elastik } & \multicolumn{3}{c}{ Spun Pile } \\
\hline $\begin{array}{c}\text { Dimensi } \\
(\mathrm{mm})\end{array}$ & \multicolumn{9}{c}{ Fix Head } & \multicolumn{1}{c}{ Fregi Beton Head } & \multicolumn{2}{c}{ Fix Head } & \multicolumn{2}{c}{ Free Head } \\
& OS & DUC & OS & DUC & OS & DUC & OS & DUC \\
\hline 300 & 1,36 & 3,50 & 1,60 & 3,00 & 1,33 & 3,50 & 1,56 & 3,00 \\
350 & 1,43 & 3,50 & 1,62 & 3,20 & 1,38 & 3,50 & 1,63 & 3,20 \\
400 & 1,33 & 3,33 & 1,69 & 3,40 & 1,31 & 3,33 & 1,70 & 3,40 \\
450 & 1,35 & 3,33 & 1,76 & 3,60 & 1,33 & 3,33 & 1,77 & 3,60 \\
500 & 1,40 & 3,67 & 1,83 & 3,80 & 1,38 & 3,67 & 1,84 & 3,80 \\
\hline
\end{tabular}

Tabel 3. Rekapitulasi nilai overstrength dan daktlitas tiang kelompok persegi beton dengan jarak 2,5D

\begin{tabular}{|c|c|c|c|c|c|c|c|c|c|c|}
\hline \multicolumn{11}{|c|}{ Jarak Antar Tiang 2,5D Kondisi Fix Head } \\
\hline \multirow{2}{*}{$\begin{array}{l}\text { Dimensi } \\
(\mathrm{mm})\end{array}$} & \multicolumn{2}{|c|}{4 Tiang } & \multicolumn{2}{|c|}{5 Tiang } & \multicolumn{2}{|c|}{6 Tiang } & \multicolumn{2}{|c|}{9 Tiang } & \multicolumn{2}{|c|}{16 Tiang } \\
\hline & OS & DUC & OS & DUC & $\mathrm{OS}$ & DUC & OS & DUC & OS & DUC \\
\hline 300 & 1,18 & 3,29 & 1,90 & 3,85 & 1,63 & 3,16 & 1,54 & 3,02 & 1,23 & 3,10 \\
\hline 350 & 1,33 & 3,32 & 1,47 & 3,32 & 1,56 & 3,49 & 1,61 & 3,35 & 1,48 & 3,38 \\
\hline 400 & 1,63 & 3,19 & 1,57 & 3,39 & 1,56 & 3,53 & 1,50 & 3,59 & 1,56 & 3,63 \\
\hline 450 & 1,57 & 3,61 & 1,56 & 3,63 & 2,25 & 3,85 & 1,86 & 3,85 & 1,57 & 3,80 \\
\hline 500 & 2,00 & 3,73 & 1,50 & 3,86 & 2,00 & 3,61 & 1,73 & 3,84 & 1,56 & 4,05 \\
\hline BP500 & 1,56 & 3,85 & 1,66 & 4,11 & 1,91 & 4,05 & 2,15 & 4,47 & 2,00 & 4,35 \\
\hline \multicolumn{11}{|c|}{ Jarak Antar Tiang 2,5D Kondisi Free Head } \\
\hline Dimensi & \multicolumn{2}{|c|}{4 Tiang } & \multicolumn{2}{|c|}{5 Tiang } & \multicolumn{2}{|c|}{6 Tiang } & \multicolumn{2}{|c|}{9 Tiang } & \multicolumn{2}{|c|}{16 Tiang } \\
\hline (mm) & OS & DUC & OS & DUC & OS & DUC & OS & DUC & OS & DUC \\
\hline 300 & 1,42 & 3,12 & 1,36 & 2,90 & 1,36 & 2,82 & 1,36 & 2,96 & 1,36 & 3,19 \\
\hline 350 & 1,33 & 3,19 & 1,33 & 3,06 & 1,40 & 3,46 & 1,35 & 3,43 & 1,45 & 3,07 \\
\hline 400 & 1,44 & 3,62 & 1,40 & 3,40 & 1,47 & 4,30 & 1,47 & 3,88 & 1,44 & 3,48 \\
\hline 450 & 1,41 & 3,89 & 1,50 & 4,10 & 1,46 & 4,26 & 1,33 & 3,50 & 1,35 & 3,56 \\
\hline 500 & 1,40 & 4,01 & 1,47 & 4,14 & 1,42 & 3,79 & 1,44 & 4,36 & 1,55 & 3,72 \\
\hline BP500 & 1,47 & 4,09 & 2,03 & 4,72 & 1,92 & 3,95 & 1,93 & 3,63 & 1,63 & 3,86 \\
\hline
\end{tabular}


Tabel 4. Rekapitulasi nilai overstrength dan daktlitas tiang kelompok persegi beton dengan jarak 3D

\begin{tabular}{|c|c|c|c|c|c|c|c|c|c|c|}
\hline \multicolumn{11}{|c|}{ Jarak Antar Tiang 3D Kondisi Fix Head } \\
\hline \multirow{2}{*}{$\begin{array}{l}\text { Dimensi } \\
(\mathrm{mm})\end{array}$} & \multicolumn{2}{|c|}{4 Tiang } & \multicolumn{2}{|c|}{5 Tiang } & \multicolumn{2}{|c|}{6 Tiang } & \multicolumn{2}{|c|}{9 Tiang } & \multicolumn{2}{|c|}{16 Tiang } \\
\hline & OS & DUC & OS & DUC & OS & DUC & OS & DUC & OS & DUC \\
\hline 300 & 1,75 & 2,66 & 1,67 & 3,08 & 1,39 & 3,02 & 1,44 & 2,94 & 1,55 & 3,24 \\
\hline 350 & 1,58 & 3,31 & 1,31 & 3,16 & 1,75 & 3,47 & 1,39 & 3,16 & 1,50 & 3,31 \\
\hline 400 & 1,61 & 3,46 & 1,48 & 3,25 & 1,67 & 3,48 & 1,77 & 3,29 & 1,63 & 3,61 \\
\hline 450 & 1,70 & 3,88 & 1,50 & 3,42 & 1,69 & 3,66 & 1,54 & 3,50 & 1,52 & 3,71 \\
\hline 500 & 1,67 & 4,12 & 1,52 & 3,86 & 1,57 & 3,79 & 1,55 & 3,90 & 1,65 & 4,20 \\
\hline BP500 & 1,63 & 4,28 & 1,74 & 4,94 & 1,75 & 3,83 & 1,80 & 4,11 & 2,08 & 4,25 \\
\hline \multicolumn{11}{|c|}{ Jarak Antar Tiang 3D Kondisi Free Head } \\
\hline Dimensi & \multicolumn{2}{|c|}{4 Tiang } & \multicolumn{2}{|c|}{5 Tiang } & \multicolumn{2}{|c|}{6 Tiang } & \multicolumn{2}{|c|}{9 Tiang } & \multicolumn{2}{|c|}{16 Tiang } \\
\hline$(\mathrm{mm})$ & OS & DUC & OS & DUC & $\mathrm{OS}$ & DUC & OS & DUC & OS & DUC \\
\hline 300 & 1,39 & 2,81 & 1,39 & 3,10 & 1,30 & 2,96 & 1,50 & 3,98 & 1,44 & 3,32 \\
\hline 350 & 1,33 & 3,08 & 1,31 & 3,16 & 1,38 & 2,81 & 1,32 & 4,06 & 1,44 & 3,70 \\
\hline 400 & 1,41 & 3,50 & 1,40 & 3,41 & 1,43 & 3,52 & 1,46 & 4,13 & 1,54 & 3,92 \\
\hline 450 & 1,42 & 4,04 & 1,41 & 3,36 & 1,43 & 3,78 & 1,42 & 3,76 & 1,46 & 4,05 \\
\hline 500 & 1,54 & 4,18 & 1,36 & 3,52 & 1,42 & 3,55 & 1,42 & 4,31 & 1,41 & 4,24 \\
\hline BP500 & 1,47 & 4,44 & 1,69 & 3,98 & 1,83 & 3,80 & 1,73 & 4,04 & 2,04 & 4,08 \\
\hline
\end{tabular}

Tabel 5. Rekapitulasi nilai overstrength dan daktlitas tiang kelompok persegi beton dengan jarak 5D

\begin{tabular}{|c|c|c|c|c|c|c|c|c|c|c|}
\hline \multicolumn{11}{|c|}{ Jarak Antar Tiang 5D Kondisi Fix Head } \\
\hline \multirow{2}{*}{$\begin{array}{c}\text { Dimensi } \\
(\mathrm{mm})\end{array}$} & \multicolumn{2}{|c|}{4 Tiang } & \multicolumn{2}{|c|}{5 Tiang } & \multicolumn{2}{|c|}{6 Tiang } & \multicolumn{2}{|c|}{9 Tiang } & \multicolumn{2}{|c|}{16 Tiang } \\
\hline & OS & DUC & $\mathrm{OS}$ & DUC & OS & DUC & OS & DUC & OS & DUC \\
\hline 300 & 1,62 & 3,19 & 1,69 & 3,61 & 1,55 & 3,28 & 1,6 & 3,21 & 1,60 & 3,46 \\
\hline 350 & 1,41 & 3,48 & 1,63 & 3,90 & 1,75 & 3,32 & 1,46 & 3,36 & 1,53 & 3,66 \\
\hline 400 & 1,68 & 3,83 & 1,48 & 3,41 & 1,56 & 3,48 & 1,58 & 3,57 &, 180 & 3,78 \\
\hline 450 & 1,78 & 3,92 & 1,71 & 3,54 & 1,53 & 3,60 & 1,59 & 3,91 & 1,62 & 3,81 \\
\hline 500 & 1,54 & 4,43 & 1,69 & 4,89 & 1,53 & 3,87 & 1,58 & 4,03 & 1,73 & 4,00 \\
\hline BP500 & 1,40 & 4,29 & 1,67 & 4,17 & 1,77 & 4,02 & 1,53 & 4,21 & 2,13 & 4,26 \\
\hline \multicolumn{11}{|c|}{ Jarak Antar Tiang 5D Kondisi Free Head } \\
\hline Dimensi & \multicolumn{2}{|c|}{4 Tiang } & \multicolumn{2}{|c|}{5 Tiang } & \multicolumn{2}{|c|}{6 Tiang } & \multicolumn{2}{|c|}{9 Tiang } & \multicolumn{2}{|c|}{16 Tiang } \\
\hline$(\mathrm{mm})$ & OS & DUC & OS & DUC & OS & DUC & OS & DUC & OS & DUC \\
\hline 300 & 1,56 & 3,24 & 1,50 & 3,37 & 1,53 & 3,06 & 1,57 & 3,37 & 1,55 & 3,22 \\
\hline 350 & 1,42 & 3,46 & 1,38 & 3,39 & 1,35 & 3,40 & 1,32 & 3,29 & 1,37 & 3,38 \\
\hline 400 & 1,39 & 3,20 & 1,50 & 4,04 & 1,38 & 3,54 & 1,41 & 3,53 & 1,47 & 3,53 \\
\hline 450 & 1,39 & 3,48 & 1,43 & 3,73 & 1,47 & 3,97 & 1,46 & 3,85 & 1,49 & 3,84 \\
\hline 500 & 1,32 & 3,87 & 1,39 & 3,93 & 1,62 & 4,32 & 1,39 & 4,01 & 1,35 & 4,13 \\
\hline BP500 & 1,50 & 4,62 & 1,73 & 4,14 & 1,92 & 4,20 & 1,74 & 4,31 & 1,81 & 4,32 \\
\hline
\end{tabular}


Tabel 6. Rekapitulasi nilai overstrength dan daktlitas tiang kelompok persegi beton dengan jarak 7D

\begin{tabular}{|c|c|c|c|c|c|c|c|c|c|c|}
\hline \multicolumn{11}{|c|}{ Jarak Antar Tiang 7D Kondisi Fix Head } \\
\hline \multirow{2}{*}{$\begin{array}{l}\text { Dimensi } \\
(\mathrm{mm})\end{array}$} & \multicolumn{2}{|c|}{4 Tiang } & \multicolumn{2}{|c|}{5 Tiang } & \multicolumn{2}{|c|}{6 Tiang } & \multicolumn{2}{|c|}{9 Tiang } & \multicolumn{2}{|c|}{16 Tiang } \\
\hline & $\mathrm{OS}$ & DUC & OS & DUC & OS & DUC & OS & DUC & $\mathrm{OS}$ & DUC \\
\hline 300 & 1,75 & 2,80 & 1,56 & 3,08 & 1,55 & 3,09 & 1,56 & 3,09 & 1,54 & 3,20 \\
\hline 350 & 1,47 & 3,06 & 1,47 & 3,18 & 1,42 & 3,34 & 1,38 & 3,20 & 1,59 & 3,66 \\
\hline 400 & 1,5 & 3,49 & 1,54 & 3,36 & 1,73 & 3,85 & 1,63 & 3,87 & 1,56 & 3,58 \\
\hline 450 & 1,54 & 3,68 & 1,59 & 3,65 & 1,65 & 3,93 & 1,59 & 4,15 & 1,54 & 3,99 \\
\hline 500 & 1,46 & 4,03 & 1,48 & 3,76 & 1,59 & 4,30 & 1,56 & 4,37 & 1,57 & 4,16 \\
\hline BP500 & 1,60 & 4,54 & 1,63 & 3,73 & 1,59 & 4,14 & 1,94 & 4,36 & 1,91 & 4,04 \\
\hline \multicolumn{11}{|c|}{ Jarak Antar Tiang 7D Kondisi Free Head } \\
\hline Dimensi & \multicolumn{2}{|c|}{4 Tiang } & \multicolumn{2}{|c|}{5 Tiang } & \multicolumn{2}{|c|}{6 Tiang } & \multicolumn{2}{|c|}{9 Tiang } & \multicolumn{2}{|c|}{16 Tiang } \\
\hline$(\mathrm{mm})$ & OS & DUC & OS & DUC & OS & DUC & OS & DUC & OS & DUC \\
\hline 300 & 1,54 & 3,14 & 1,56 & 3,27 & 1,58 & 3,36 & 1,57 & 3,20 & 1,60 & 3,47 \\
\hline 350 & 139 & 3,49 & 1,35 & 3,34 & 1,39 & 3,38 & 1,36 & 3,61 & 1,36 & 3,58 \\
\hline 400 & 1,33 & 3,10 & 1,39 & 3,04 & 1,48 & 3,69 & 1,44 & 3,47 & 1,48 & 3,72 \\
\hline 450 & 1,32 & 2,99 & 1,41 & 3,66 & 1,44 & 3,90 & 1,42 & 3,75 & 1,46 & 3,81 \\
\hline 500 & 1,32 & 3,21 & 1,44 & 4,30 & 1,54 & 4,65 & 1,36 & 3,98 & 1,36 & 3,93 \\
\hline BP500 & 1,38 & 3,93 & 1,59 & 4,28 & 1,92 & 4,31 & 1,74 & 4,20 & 1,76 & 4,13 \\
\hline
\end{tabular}

Tabel 7. Rekapitulasi nilai overstrength dan daktlitas tiang kelompok spun pile dengan jarak 2,5D

\begin{tabular}{|c|c|c|c|c|c|c|c|c|c|c|}
\hline \multicolumn{11}{|c|}{ Jarak Antar Tiang 2,5D Kondisi Fix Head } \\
\hline \multirow{2}{*}{$\begin{array}{c}\text { Dimensi } \\
(\mathrm{mm})\end{array}$} & \multicolumn{2}{|c|}{4 Tiang } & \multicolumn{2}{|c|}{5 Tiang } & \multicolumn{2}{|c|}{6 Tiang } & \multicolumn{2}{|c|}{9 Tiang } & \multicolumn{2}{|c|}{16 Tiang } \\
\hline & OS & DUC & OS & DUC & OS & DUC & OS & DUC & $\mathrm{OS}$ & DUC \\
\hline 300 & 1,83 & 3,49 & 1,48 & 3,07 & 1,70 & 3,45 & 1,83 & 3,58 & 1,67 & 3,06 \\
\hline 350 & 1,83 & 3,25 & 1,43 & 3,26 & 1,64 & 3,41 & 2,25 & 3,66 & 1,64 & 3,30 \\
\hline 400 & 1,82 & 3,66 & 1,67 & 3,17 & 1,80 & 3,57 & 1,82 & 3,61 & 1,62 & 3,48 \\
\hline 450 & 1,85 & 3,62 & 1,61 & 3,60 & 2,29 & 3,65 & 2,00 & 3,93 & 1,83 & 3,72 \\
\hline 500 & 1,75 & 3,33 & 1,50 & 3,49 & 2,00 & 3,80 & 2,00 & 4,17 & 1,9 & 4,22 \\
\hline BP500 & 1,64 & 3,46 & 1,73 & 3,85 & 2,14 & 4,12 & 2,13 & 4,11 & 2,00 & 4,81 \\
\hline \multicolumn{11}{|c|}{ Jarak Antar Tiang 2,5D Kondisi Free Head } \\
\hline \multirow{2}{*}{$\begin{array}{c}\text { Dimensi } \\
(\mathrm{mm})\end{array}$} & \multicolumn{2}{|c|}{4 Tiang } & \multicolumn{2}{|c|}{5 Tiang } & \multicolumn{2}{|c|}{6 Tiang } & \multicolumn{2}{|c|}{9 Tiang } & \multicolumn{2}{|c|}{16 Tiang } \\
\hline & OS & DUC & OS & DUC & OS & DUC & $\mathrm{OS}$ & DUC & $\mathrm{OS}$ & DUC \\
\hline 300 & 1,43 & 3,53 & 1,41 & 3,34 & 1,40 & 3,48 & 2,33 & 3,29 & 1,33 & 3,02 \\
\hline 350 & 1,33 & 3,50 & 1,33 & 3,63 & 1,46 & 3,64 & 1,36 & 3,43 & 1,33 & 3,22 \\
\hline 400 & 1,46 & 3,77 & 1,46 & 3,55 & 1,47 & 3,73 & 1,47 & 3,56 & 1,52 & 3,40 \\
\hline 450 & 1,41 & 3,69 & 1,42 & 4,04 & 1,75 & 3,61 & 1,38 & 3,52 & 1,45 & 3,51 \\
\hline 500 & 1,36 & 4,19 & 1,39 & 4,21 & 1,44 & 3,84 & 1,46 & 3,78 & 1,58 & 3,82 \\
\hline BP500 & 1,44 & 4,92 & 2,12 & 4,42 & 2,00 & 3,97 & 2,09 & 4,00 & 2,09 & 4,58 \\
\hline
\end{tabular}

Tabel 8. Rekapitulasi nilai overstrength dan daktlitas tiang kelompok spun pile dengan jarak 3D

\begin{tabular}{|c|c|c|c|c|c|c|c|c|c|c|}
\hline \multicolumn{11}{|c|}{ Jarak Antar Tiang 3D Kondisi Fix Head } \\
\hline Dimensi & \multicolumn{2}{|c|}{4 Tiang } & \multicolumn{2}{|c|}{5 Tiang } & \multicolumn{2}{|c|}{6 Tiang } & \multicolumn{2}{|c|}{9 Tiang } & \multicolumn{2}{|c|}{16 Tiang } \\
\hline$(\mathrm{mm})$ & OS & DUC & $\mathrm{OS}$ & DUC & OS & DUC & OS & DUC & OS & DUC \\
\hline 300 & 1,83 & 3,40 & 1,6 & 3,04 & 1,78 & 3,36 & 1,56 & 3,00 & 1,54 & 3,07 \\
\hline 350 & 1,67 & 3,67 & 1,63 & 3,38 & 1,64 & 3,12 & 1,64 & 3,24 & 1,44 & 3,28 \\
\hline 400 & 1,83 & 3,96 & 1,65 & 3,33 & 1,76 & 3,56 & 1,58 & 3,41 & 1,47 & 3,47 \\
\hline 450 & 2,00 & 4,05 & 1,60 & 3,74 & 1,73 & 3,43 & 1,57 & 3,43 & 1,50 & 3,51 \\
\hline 500 & 1,71 & 4,25 & 1,78 & 3,92 & 1,68 & 3,68 & 1,73 & 3,70 & 1,67 & 3,79 \\
\hline BP500 & 1,64 & 3,94 & 1,82 & 4,14 & 2,13 & 4,60 & 1,93 & 4,09 & 2,10 & 3,91 \\
\hline \multicolumn{11}{|c|}{ Jarak Antar Tiang 3D Kondisi Free Head } \\
\hline Dimensi & \multicolumn{2}{|c|}{4 Tiang } & \multicolumn{2}{|c|}{5 Tiang } & \multicolumn{2}{|c|}{6 Tiang } & \multicolumn{2}{|c|}{9 Tiang } & \multicolumn{2}{|c|}{16 Tiang } \\
\hline$(\mathrm{mm})$ & OS & DUC & $\mathrm{OS}$ & DUC & $\mathrm{OS}$ & DUC & $\mathrm{OS}$ & DUC & OS & DUC \\
\hline 300 & 1,7 & 3,38 & 1,37 & 2,97 & 1,40 & 3,03 & 1,43 & 3,13 & 1,44 & 3,12 \\
\hline 350 & 1,71 & 3,04 & 1,33 & 3,18 & 1,39 & 3,44 & 1,55 & 3,10 & 1,38 & 3,45 \\
\hline 400 & 1,39 & 3,47 & 1,35 & 3,30 & 1,39 & 3,41 & 1,4 & 3,31 & 1,53 & 3,44 \\
\hline
\end{tabular}


Lanjutan Tabel 8

\begin{tabular}{ccccccccccc}
\hline $\begin{array}{c}\text { Dimensi } \\
(\mathrm{mm})\end{array}$ & \multicolumn{2}{c}{ 4 Tiang } & \multicolumn{2}{c}{ 5 Tiang } & \multicolumn{2}{c}{ 6 Tiang } & \multicolumn{2}{c}{ 9 Tiang } & \multicolumn{2}{c}{ 16 Tiang } \\
\hline 450 & 1,35 & DUC & OS & DUC & OS & DUC & OS & DUC & OS & DUC \\
\hline 500 & 1,33 & 3,45 & 1,42 & 3,63 & 1,36 & 3,24 & 1,38 & 3,36 & 1,41 & 3,57 \\
BP500 & 1,50 & 4,56 & 1,78 & 3,77 & 1,67 & 3,60 & 1,75 & 3,89 & 1,39 & 3,84 \\
\hline
\end{tabular}

Tabel 9. Rekapitulasi nilai overstrength dan daktlitas tiang kelompok spun pile dengan jarak 5D

\begin{tabular}{|c|c|c|c|c|c|c|c|c|c|c|}
\hline \multicolumn{11}{|c|}{ Jarak Antar Tiang 5D Kondisi Fix Head } \\
\hline \multirow{2}{*}{$\begin{array}{c}\text { Dimensi } \\
(\mathrm{mm})\end{array}$} & \multicolumn{2}{|c|}{4 Tiang } & \multicolumn{2}{|c|}{5 Tiang } & \multicolumn{2}{|c|}{6 Tiang } & \multicolumn{2}{|c|}{9 Tiang } & \multicolumn{2}{|c|}{16 Tiang } \\
\hline & OS & DUC & OS & DUC & $\mathrm{OS}$ & DUC & $\mathrm{OS}$ & DUC & OS & DUC \\
\hline 300 & 1,75 & 3,11 & 1,65 & 3,14 & 1,57 & 3,21 & 1,55 & 3,21 & 1,6 & 3,46 \\
\hline 350 & 1,60 & 3,36 & 1,58 & 3,10 & 1,62 & 3,17 & 1,44 & 3,31 & 1,63 & 3,66 \\
\hline 400 & 1,83 & 3,71 & 1,55 & 3,43 & 1,79 & 3,74 & 1,77 & 3,51 & 1,80 & 3,78 \\
\hline 450 & 1,59 & 3,76 & 1,70 & 3,62 & 1,71 & 3,90 & 1,82 & 3,76 & 1,62 & 3,81 \\
\hline 500 & 1,71 & 3,86 & 1,62 & 3,97 & 1,64 & 3,97 & 1,67 & 4,20 & 1,73 & 4,00 \\
\hline BP500 & 1,82 & 4,59 & 1,78 & 4,10 & 1,91 & 4,35 & 1,67 & 4,42 & 2,13 & 4,26 \\
\hline \multicolumn{11}{|c|}{ Jarak Antar Tiang 5D Kondisi Free Head } \\
\hline \multirow{2}{*}{$\begin{array}{c}\text { Dimensi } \\
(\mathrm{mm})\end{array}$} & \multicolumn{2}{|c|}{4 Tiang } & \multicolumn{2}{|c|}{5 Tiang } & \multicolumn{2}{|c|}{6 Tiang } & \multicolumn{2}{|c|}{9 Tiang } & \multicolumn{2}{|c|}{16 Tiang } \\
\hline & OS & DUC & $\mathrm{OS}$ & DUC & $\mathrm{OS}$ & DUC & $\mathrm{OS}$ & DUC & OS & DUC \\
\hline 300 & 1,41 & 3,27 & 1,43 & 3,35 & 1,36 & 3,02 & 1,40 & 3,44 & 1,43 & 3,38 \\
\hline 350 & 1,25 & 3,28 & 138 & 3,78 & 1,29 & 3,31 & 1,44 & 3,62 & 1,40 & 3,40 \\
\hline 400 & 1,46 & 3,50 & 1,47 & 3,75 & 1,41 & 3,31 & 1,39 & 3,59 & 1,43 & 3,54 \\
\hline 450 & 1,35 & 3,48 & 1,44 & 3,91 & 1,38 & 3,30 & 1,42 & 3,52 & 1,50 & 3,82 \\
\hline 500 & 1,67 & 3,83 & 1,65 & 4,24 & 1,55 & 3,58 & 1,53 & 3,67 & 1,56 & 4,01 \\
\hline BP500 & 1,47 & 4,19 & 1,91 & 4,49 & 2,00 & 4,15 & 1,79 & 3,94 & 2,33 & 4,26 \\
\hline
\end{tabular}

Tabel 10. Rekapitulasi nilai overstrength dan daktlitas tiang kelompok spun pile dengan jarak 7D

\begin{tabular}{|c|c|c|c|c|c|c|c|c|c|c|}
\hline \multicolumn{11}{|c|}{ Jarak Antar Tiang 7D Kondisi Fix Head } \\
\hline \multirow{2}{*}{$\begin{array}{c}\text { Dimensi } \\
(\mathrm{mm})\end{array}$} & \multicolumn{2}{|c|}{4 Tiang } & \multicolumn{2}{|c|}{5 Tiang } & \multicolumn{2}{|c|}{6 Tiang } & \multicolumn{2}{|c|}{9 Tiang } & \multicolumn{2}{|c|}{16 Tiang } \\
\hline & OS & DUC & OS & DUC & OS & DUC & OS & DUC & OS & DUC \\
\hline 300 & 1,75 & 3,12 & 1,58 & 3,28 & 1,57 & 3,11 & 1,60 & 3,13 & 1,64 & 3,35 \\
\hline 350 & 1,50 & 3,35 & 1,53 & 3,67 & 1,60 & 3,52 & 1,50 & 3,47 & 1,49 & 3,28 \\
\hline 400 & 1,83 & 3,67 & 1,72 & 3,71 & 1,67 & 3,84 & 1,78 & 3,63 & 1,64 & 3,52 \\
\hline 450 & 1,59 & 3,61 & 1,63 & 3,85 & 1,63 & 3,74 & 1,60 & 3,78 & 1,50 & 3,50 \\
\hline 500 & 1,86 & 4,04 & 1,79 & 3,93 & 1,78 & 3,91 & 1,74 & 4,03 & 1,56 & 3,94 \\
\hline BP500 & 2,14 & 4,29 & 1,83 & 4,32 & 2,13 & 3,96 & 1,89 & 4,30 & 1,73 & 4,11 \\
\hline \multicolumn{11}{|c|}{ Jarak Antar Tiang 7D Kondisi Free Head } \\
\hline \multirow{2}{*}{$\begin{array}{c}\text { Dimensi } \\
(\mathrm{mm})\end{array}$} & \multicolumn{2}{|c|}{4 Tiang } & \multicolumn{2}{|c|}{5 Tiang } & \multicolumn{2}{|c|}{6 Tiang } & \multicolumn{2}{|c|}{9 Tiang } & \multicolumn{2}{|c|}{16 Tiang } \\
\hline & OS & DUC & OS & DUC & OS & DUC & OS & DUC & OS & DUC \\
\hline 300 & 1,57 & 3,41 & 1,43 & 3,26 & 1,46 & 3,46 & 1,60 & 3,13 & 1,43 & 3,18 \\
\hline 350 & 1,36 & 4,00 & 1,39 & 3,65 & 1,38 & 3,70 & 1,39 & 3,58 & 1,34 & 3,43 \\
\hline 400 & 1,50 & 4,10 & 1,42 & 3,75 & 1,73 & 3,67 & 1,52 & 3,94 & 1,58 & 3,73 \\
\hline 450 & 1,50 & 4,34 & 1,5 & 4,10 & 1,43 & 3,75 & 1,59 & 4,19 & 1,56 & 3,85 \\
\hline 500 & 2,13 & 4,50 & 1,49 & 4,25 & 1,62 & 3,84 & 1,56 & 4,20 & 1,47 & 4,21 \\
\hline BP500 & 1,39 & 4,74 & 1,81 & 4,34 & 2,00 & 4,09 & 2,00 & 4,05 & 2,00 & 4,23 \\
\hline
\end{tabular}

\section{KESIMPULAN DAN SARAN}

\section{Kesimpulan}

Dari hasil dan pembahasan pada penelitian ini dapat ditarik beberapa kesimpulan yaitu: 
1. Berdasarkan hasil analisis menggunakan program LPILE dan Group, ditarik kesimpulan bahwa tiang dengan kondisi kepala tiang Fix Head cenderung mampu menahan beban lateral relatif lebih besar dibanding kondisi kepala tiang Free Head.

2. Peningkatan beban lateral terbesar dengan menggunakan tiang batter pile terdapat pada 16 tiang kelompok spun pile dengan jarak antar tiang 2,5D dan 16 tiang kelompok persegi beton dengan jarak antar tiang 3D yaitu sebesar $750 \%$ dari kekuatan normalnya.

3. Berdasarkan hasil analisis menggunakan program LPile, kisaran nilai daktilitas 3,00 - 4,00 dan nilai overstrength sebesar 1,10 - 1,77 dari keseluruhan tiang tunggal yang diuji.

4. Berdasarkan hasil analisis mengunakan program Group, kisaran nilai daktilitas sebesar 2,66 - 4,89 dan nilai overstrength sebesar 1,18 - 2,60 dari keseluruhan tiang kelompok yang diuji.

5. Berdasarkan hasil analisis grafik daktilitas dan overstrength, cenderung terjadi kegagalan pada tiang kelompok spun pile pada saat tertentu dan terus mampu memikul beban lateral, diduga kegagalan terjadi pada lapisan tanah.

\section{Saran}

Berdasarkan hasil penelitian yang telah dilakukan terdapat beberapa saran yang sekiranya dapat menjadi masukan untuk objek studi dan penelitian selanjutnya. Beberapa saran tersebut diantaranya adalah sebagai berikut:

1. Perlu dilakukan beberapa analisis pada tipe tiang dengan ukuran tiang yang berbeda-beda dan jenis tanah yang lebih bervariasi.

2. Perlu dilakukan analisis terhadap tiang seperti, besarnya beban aksial dan momen maximum yang dapat diterima tiang tunggal maupun tiang kelompok.

3. Perlu dilakukannya analisa tiang kelompok batter pile dengan sudut kemiringan yang bervariasi.

\section{DAFTAR PUSTAKA}

Bowles, J. E. Analisis dan Desain Pondasi Jilid 1 Edisi Keempat. Jakarta: Penerbit Erlangga, 1997.

Propika, Jaka dan Jenny Caroline. Peningkatan Daktilitas Hollow Pile dengan Penambahan Ratio Spiral dan Beton Cor Setempat. Surabaya: Fakultas Teknik Sipil dan Perencanaan, 2017.

Badan Standarisasi Nasional. "Standar Perencanaan Ketahanan Gempa Untuk Struktur Bangunan Gedung (SNI 1726:2002)”. Jakarta. Badan Standararisasi Nasional. 2002.

Badan Standarisasi Nasional. "Tata Cara Perhitungan Struktur Beton Untuk Bangunan Gedung (SNI 2847:2002)”. Jakarta. Badan Standarisasi Nasional. 2002.

Convention on International Civil Aviation, Chicago. Desember, 1944.

Wayne, C. T. “Foundation Design”. U.S.A: Prentice Hall of International, Inc., Englewood Cliffs. 1962. 